\title{
Variation within the Bird Community of a Rehabilitated Urban Environment, Case of the Félix Houphouët-Boigny University Campus (Côte d'Ivoire)
}

Ekoun Michaël KONAN ${ }^{1 *}$, Valérie Florence GUETONDE ${ }^{2}$, Coffi Jean Magloire NIAMIEN ${ }^{1}$, Kouassi Hilaire YAOKOKORE-BEIBRO ${ }^{3}$

\author{
${ }^{* 1}$ Department of Animal Biology, UFR of Biological Sciences, Peleforo Gon Coulibaly University of Korhogo \\ Korhogo, Côte d'Ivoire \\ Email: micekoun [AT] gmail.com \\ ${ }^{2}$ Houphouët-Boigny high school in Korhogo \\ Korhogo, Côte d'Ivoire \\ Email: gvalerieflorence [AT] gmail.com
${ }^{1}$ Department of Animal Biology, UFR of Biological Sciences, Peleforo Gon Coulibaly University of Korhogo Korhogo, Côte d'Ivoire
Email: niamien.coffi [AT] gmail.com
${ }^{3}$ Biology of Conservation and Management of Wildlife Research Unit, Laboratory of Natural Environments and Biodiversity Conservation, UFR Biosciences, Félix HOUPHOUËT-BOIGNY University
Abidjan, Côte d'Ivoire
Email: hyaokokore [AT] gmail.com

\begin{abstract}
In order to understand the ecological impact of the rehabilitation of the Félix Houphouët-Boigny University Campus on the bird community, a study was carried out over two months (October-November 2016). The ornithological inventory carried out by the IPA method in five different habitats identified on the campus gave a total species richness of 51 bird species of 41 genera, 27 families and 13 orders for 1374 birds, with $H^{\prime}=2.93$ and $J=0.74$. Five species dominate the population (819 individuals, $\mathrm{Fr}=59,61 \%)$. These are Bubulcus ibis (9.32 \%), Apus affinis (8.95\%), Corvus albus (19.94\%), Ploceus cucullatus (10.48\%), Lonchura cucullata (10.92 \%). The most diversified habitat is the Habitations (26 bird species), while the most abundant is the Brush (416 individuals). Only seven species are common to all sampled habitats. Thus, 12 species observed on campus formerly could not be observed during the present study. Similarly, 18 species observed in this study were not observed in the previous study. The profound transformation of the environment following the rehabilitation has led to a slight increase in diversity but a significant drop in numbers. It is therefore important to better understand the different interactions between the components of the habitat and the various species involved. Such data would be crucial in urban planning policies.
\end{abstract}

Keywords--- Urban ecology, Avifauna, Biodiversity, University campus, Côte d'Ivoire

\section{INTRODUCTION}

The city of Abidjan, the economic capital of Côte d'Ivoire, is a rapidly growing agglomeration with the expansion from 10 to 13 communes. This poses the thorny problem of the place of nature in the city. Indeed, biological diversity is still considered, at least in popular discourse, as an issue reserved for natural environments far from urban areas [10]. City and nature are therefore generally seen as incompatible, with the city embodying the remoteness of nature [14]. Fortunately, the issue of urban biodiversity conservation has now become an object of scientific research and an important issue in urban policies [3]. This interest would be justified by the fact that urban environments are a complex and dynamic mosaic of biotopes [18]. They provide multiple habitats for many species of animals and plants and host a substantial portion of global biological diversity [19]. Thus, the main question at the heart of these studies is to understand and even predict the impact of the densification of the city on its biodiversity, and to indicate to urban decision-makers the key elements to preserve or reconstitute in order to preserve elements of nature in the city, in order to avoid transforming urban environments into gigantic mineral blocks, breaking any ecological connection and forcing the city to evolve in an empty universe of life [12]. 
To measure the quality of habitat in urban areas, it's important to select zoological groups that are easy to follow and that at all times capture the state of the habitat under consideration. One of the zoological groups able to provide fairly satisfactory answers is birds, which are considered to be very good indicators of ecological change [22].

This study was carried out in an urbanized environment represented by the Félix Houphouët Boigny University Campus, the first public university in Côte d'Ivoire which has the advantage of presenting the physiognomy of a city in miniature. Thanks to the post-electoral crisis in Côte d'Ivoire, this university has undergone a profound rehabilitation that has contributed to changing its global landscape.

Thus, the objective of this study is to understand the impact of the rehabilitation of this campus on the diversity of birds by assessing the links between bird communities and elements of the landscape.

\section{MATERIALS AND METHODS}

\subsection{Description of the study area}

The Félix Houphouët Boigny University, located in the commune of Cocody in the east of the city of Abidjan. The Campus of Félix Houphouët Boigny University, formerly known as University of Cocody, covers an area of 205 hectares [16]. Located between $5^{\circ} 19^{\prime} \mathrm{N}$ and $4^{\circ} 01^{\prime} \mathrm{W}$, it's bounded to the north by the road to Bingerville, to the south by the road leading to the Riviéra Golf, to the east by the road leading to the third bridge (Henri Konan Bédié Bridge) and to the west by the Cocody Hospital and University Center (CHU) (Figure 1). It has a hot and humid equatorial climate with four seasons: a long rainy season (April-July); a short rainy season (October-November); a short dry season (August-September) and a long dry season (December-March) [7].

The university campus's vegetation is represented by large, well-maintained lawns bordered by ornamental plants. The peripheral parts of the campus, less frequented and poorly maintained, sometimes turn into real brush composed of tall grass such as Panicum maximum Jacq. (Poaceae). Between the buildings, there are a few large trees and non-woody plants such as Coco nucifera Jacq. (Arecaceae) and palm trees Elaeis guineensis L. (Arecaceae). The site contains three heavily forested areas. These are the National Center for Floristics (CNF), the garden of the restaurant complex "les Palmiers" and the closed park of the UFR Biosciences. This vegetation is fairly recent and dates from the rehabilitation, as [25] report that in 2008, 14 hectares of the campus were occupied by mosaics of fallows and food crops that no longer exist today.

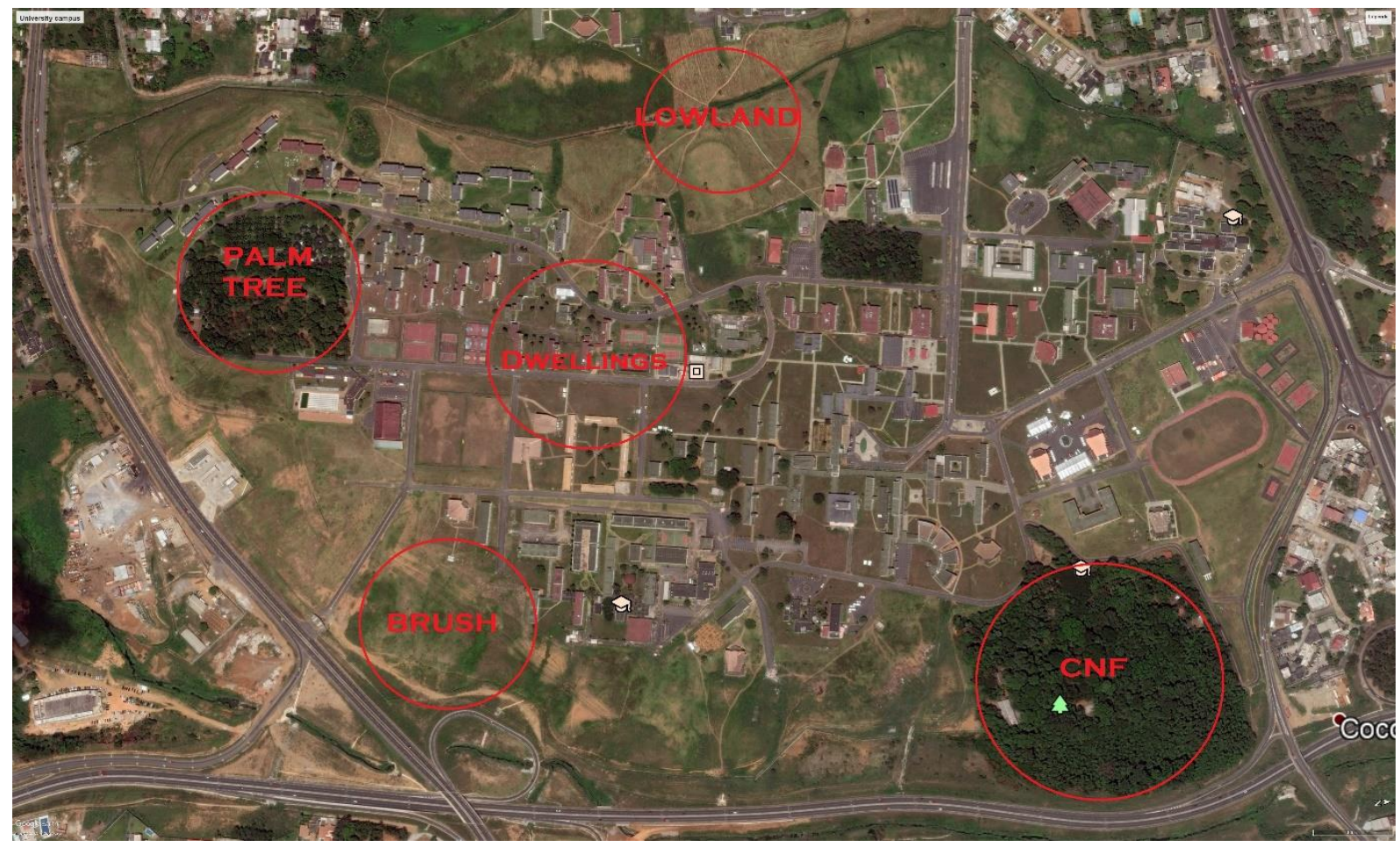

Figure 1: AERIAL view of the Félix Houphouët-Boigny University campus with location of the different habitats. 


\subsection{Methods}

\subsubsection{Description of the different habitats sampled}

Across the campus, five habitats were chosen and were the subject of an ornithological inventory. These are the habitats of Lowland, Scrub, Palm Trees, Dwellings and the National Floristic Center.

The Lowland habitat $\left(5^{\circ} 20^{\prime} 38.8^{\prime \prime} \mathrm{N}\right.$ and $\left.3^{\circ} 59^{\prime} 29.6^{\prime \prime} \mathrm{W}\right)$ is crossed by a drainage channel, with vegetation mainly consisting of creeping plants regularly mowed and forming a lawn and dense herbaceous vegetation along the canal, made up of reeds (g. Phragmites), other grasses and bananas ( $g$. Musa) which give this habitat the appearance of a wetland. (Figure 2a).

The CNF ( $5^{\circ} 20^{\prime} 50.4^{\prime \prime} \mathrm{N}$ and $\left.3^{\circ} 59^{\prime} 02.4^{\prime \prime} \mathrm{W}\right)$, with an area of 10 ha is a fully planted forest environment which includes a botanical garden (arboretum) and a fallow looking like a young secondary forest (Figure 2b). The vegetation of the arboretum consists of forest species Triplochiton scleroxylon (Triplochitonaceae), Sterculia tragacanta (Sterculiaceae), Entondrophragma cylindrium (Meliaceae) and savanna species Vitellaria paradoxa (Sapotaceae) and Adansonia digitalia (Bombacaceae).

Habitations habitat $\left(5^{\circ} 20^{\prime} 32.3^{\prime} \mathrm{N}\right.$ and $3^{\circ} 59^{\prime} 16.2^{\prime} \mathrm{W}$ ) is represented by buildings (offices, amphitheatres, university residences, restaurants), asphalt roads, street lighting and sports fields. Its vegetation consists largely of cover plants Chysopogon aciculatus (poaceae) forming regularly mowed lawns, bordered by ornamental plants of various species, as well as coconut and woody plants, most of which are ornamental trees (Figure 2c).

Palm Tree habitat $\left(5^{\circ} 20^{\prime} 15.3^{\prime \prime} \mathrm{N}\right.$ and $\left.3^{\circ} 59^{\prime} 24.9^{\prime \prime} \mathrm{W}\right)$, a place to relax and stroll, is made up of a restaurant complex associated with a garden. Restaurants take up less than a quarter of the space. One-fifth of the garden is planted with Elaeis guineensis L. oil palms (Arecaceae) and the rest for the most part Eucalyptus. The ground is covered with lawn (Figure 2d).

Brush habitat $\left(5^{\circ} 20^{\prime} 36.7^{\prime \prime} \mathrm{N}\right.$ and $\left.3^{\circ} 59^{\prime} 01.0^{\prime \prime} \mathrm{W}\right)$ consists mainly of tall grasses with open spikes such as Panicum maximum. A few banana trees (g. Musa) can be seen here and there. At its periphery, a garbage bin is regularly supplied with organic waste (Figure 2e).

These five habitats, determined by the physiognomy of their landscapes, represent all possible habitat types visible on campus.

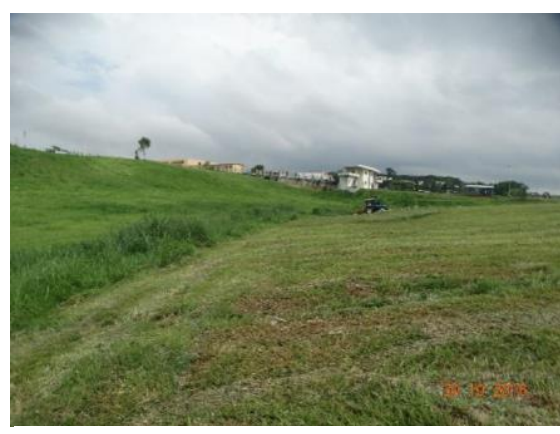

(a) View of Lowland habitat

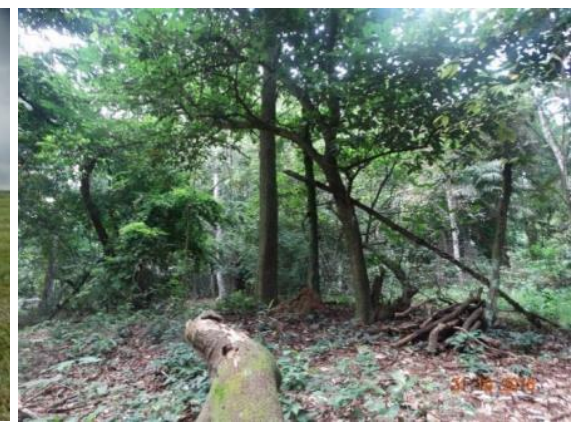

(b) View of CNF habitat

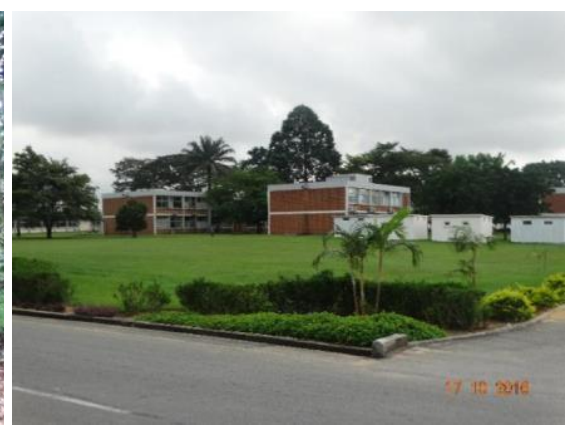

(c) View of Habitations habitat

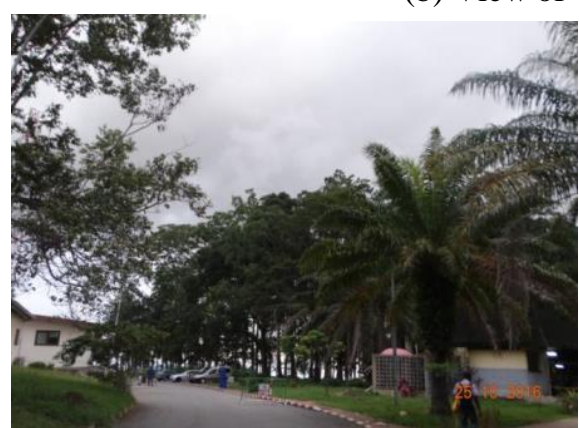

(d) View of Palm tree habitat

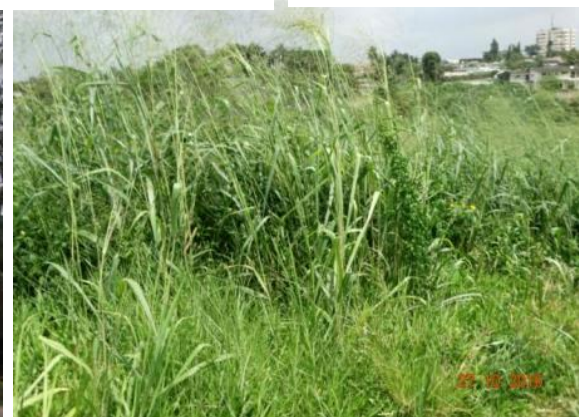

(e) View of Brush habitat

Figure 2: DIFFERENT habitat types sampled on the university campus

\subsubsection{Data collection}

The Point Abundance Index (API) method [4] was used in this study. On each habitat, a listening point was identified. These points are sufficiently distant from each other (at least $300 \mathrm{~m}$ ). From each point, all the birds observed or heard within a radius of 150 meters were inventoried, ie a covered area of 70,686 $\mathrm{m}^{2}$ (7 ha) per habitat and $353,429 \mathrm{~m}^{2}$ for all the sites (35 ha). 
Ornithological surveys were conducted for two months, from October to November 2016, during which each habitat was sampled once a week from 6:00 a.m. to 6:20 p.m. During one day of inventory carried out per habitat, seven observation sessions of $20 \mathrm{~min}$ each are carried out. Two consecutive sessions are separated by a time interval of 1:40, for a total of $140 \mathrm{~min}$ per habitat per week and an overall sampling effort of 5,600 min of data collection across the campus.

Each survey mentions both the species specific richness and relative abundance. These were recorded by sight and listening and identified with the help of the West African Birds guide [6] and the CD-Rom of the cries and songs of the Birds of 'Africa [8], for those heard.

Lists of bird species are given in the phylogenetic order used by [5]. The nomenclature used is the 2019 catalogue of life.

\subsubsection{Data processing}

The specific richness of the site is obtained by the formula $S=\Sigma$ Species. The relative frequency of each species in the community is determined by $\mathrm{Fr}=\mathrm{ni} / \mathrm{N} \times 100$. It was used to determine the abundance index. According to [21] a species is said to be dominant (D) if $\mathrm{Fr} \geq 5 \%$; it is regular (Re) if $1 \% \leq \mathrm{Fr}<5 \%$; it is said to be rare (Ra) if $0.2 \% \leq \mathrm{Fr}<1$; it is accidental (Ac) if Fr $<0.2 \%$. The Shannon-Wiener [20] and Equitabilié [1] diversity indices are expressed as $\mathrm{H}^{\prime}=-\Sigma\left(\mathrm{ni}^{\prime} / \mathrm{N}\right)$ $\mathrm{x} \ln (\mathrm{ni} / \mathrm{N})$ and $\mathrm{J}=\mathrm{H}^{\prime} / \operatorname{lnS}$, respectively. The different populations of the sampled habitats were compared with each other by the similarity index [2] expressed as follows: $\mathrm{Si}=(2 \times \mathrm{C} / \mathrm{A}+\mathrm{B}) \times 100$. In terms of preferred bird habitat, we thus determine the species of wetlands (E), species of open areas (f), species of secondary forest (F) [22], anthropophilic species (V) [9]. The international threat status of each species was determined according to IUCN (2018). To process all the data collected, three types of multivariate analyzes were used. These are principal component analysis, hierarchical ascending classification analysis (ACAH), analysis of variance (ANOVA) and the General Linear Model.

\section{RESULTS AND DISCUSSION}

\subsection{University campus global avifauna}

A total of 51 species of birds of 41 genera, 27 families and 13 orders were recorded, or 1,374 birds, with H' $=2.93$ and J $=0.74$. The Passeriformes, with 26 species from 14 families are more numerous, against 25 species in 13 families for the 12 non-Passeriform orders. In terms of abundance, the Passeriformes are more numerous, with 813 individuals, followed by the Apodiformes (213 individuals) and the Pelecaniformes (129 individuals) (Table I).

Table I: List of species and some characteristics of birds observed on the Félix Houphouët-Boigny university campus in October and November 2016.

\begin{tabular}{|c|c|c|c|c|c|c|c|c|}
\hline Orders / Families / Species & $\mathbf{P H}$ & IUCN & Hab & Pal & Bas & Bro & CNF & Code \\
\hline \multicolumn{9}{|l|}{ PELECANIFORMS } \\
\hline \multicolumn{9}{|l|}{ Ardeidae } \\
\hline Bubulcus ibis (Linnaeus, 1758) & $E / f$ & $\mathrm{LC}$ & 51 & 11 & 48 & 17 & 1 & Bubib \\
\hline Butorides striata (Linnaeus, 1758) & $\mathrm{E}$ & $\mathrm{LC}$ & - & - & 1 & - & - & Butst \\
\hline \multicolumn{9}{|l|}{ ACCIPITRIFORMS } \\
\hline \multicolumn{9}{|l|}{ Accipitridae } \\
\hline Milvus migrans (Boddaert, 1783) & f. & $\mathrm{LC}$ & 16 & 7 & 4 & 12 & 10 & Milmi \\
\hline Accipiter tachiro ( Daudin, 1800) & $\mathrm{F}$ & $\mathrm{LC}$ & - & - & - & - & 1 & Accta \\
\hline Accipiter badius (JF Gmelin , 1788) & $\mathrm{F}$ & $\mathrm{LC}$ & 1 & 2 & 2 & 1 & 3 & Accba \\
\hline \multicolumn{9}{|l|}{ FALCONIFORMS } \\
\hline \multicolumn{9}{|l|}{ Falconidae } \\
\hline Falco ardosiaceus Vieillot, 1823 & f. & $\mathrm{LC}$ & 2 & - & - & 1 & - & Falar \\
\hline \multicolumn{9}{|l|}{ GRUIFORMS } \\
\hline \multicolumn{9}{|l|}{ Rallidae } \\
\hline Amaurornis flavirostra ( Swainson, 1837) & $\mathrm{E}$ & $\mathrm{LC}$ & - & - & 6 & - & - & Amafl \\
\hline Gallinula chloropus (Linnaeus, 1758) & E & $\mathrm{LC}$ & - & - & 11 & - & - & Galch \\
\hline \multicolumn{9}{|l|}{ COLUMBIFORMS } \\
\hline \multicolumn{9}{|l|}{ Columbidae } \\
\hline Streptopelia senegalensis (Linnaeus, 1766) & f. & $\mathrm{LC}$ & 5 & - & 2 & 10 & - & Strse \\
\hline Streptopelia semitorquata ( Ruppell , 1837) & f. & $\mathrm{LC}$ & 5 & 13 & 5 & 7 & 4 & Strsm \\
\hline \multicolumn{9}{|l|}{ PSITTACIFORMS } \\
\hline \multicolumn{9}{|l|}{ Psittacidae } \\
\hline Psittacus erithacus Linnaeus, 1758 & $\mathrm{~F}$ & Seen & - & 2 & - & - & 2 & Psier \\
\hline Psittacus timneh & $\mathrm{F}$ & Seen & - & 5 & - & - & 2 & Psiti \\
\hline Poicephalus senegalus (Linnaeus, 1766) & f. & $\mathrm{LC}$ & 8 & 7 & - & - & 4 & Poise \\
\hline Psittacula krameri ( Scopoli , 1769) & f. & $\mathrm{LC}$ & 4 & 10 & - & - & 2 & Psikr \\
\hline
\end{tabular}




\begin{tabular}{|c|c|c|c|c|c|c|c|c|}
\hline \multirow{2}{*}{\multicolumn{9}{|c|}{$\begin{array}{l}\text { Orders / Families / Species } \\
\text { MUSOPHAGIFORMS }\end{array}$}} \\
\hline & & & & & & & & \\
\hline \multicolumn{9}{|l|}{ Musophagidae } \\
\hline Crinifer piscator ( Boddaert, 1783) & f. & $\mathrm{LC}$ & - & 5 & - & - & 5 & Cripi \\
\hline \multicolumn{9}{|l|}{ CUCULIFORMS } \\
\hline \multicolumn{9}{|l|}{ Cuculidae } \\
\hline Chrysococcyx caprius ( Boddaert, 1783) & f. & $\mathrm{LC}$ & 1 & - & - & - & - & Chrca \\
\hline Centropus senegalensis (Linnaeus, 1766) & f. & $\mathrm{LC}$ & - & - & 4 & 3 & - & Cense \\
\hline \multicolumn{9}{|l|}{ STRIGIFORMS } \\
\hline \multicolumn{9}{|l|}{ Tytonidae } \\
\hline \multirow{2}{*}{\multicolumn{9}{|c|}{ APODIFORMS }} \\
\hline & & & & & & & & \\
\hline \multicolumn{9}{|l|}{ Apodidae } \\
\hline Telacanthura ussheri (Sharpe, 1870) & $\mathrm{F}$ & $\mathrm{LC}$ & 10 & - & - & - & - & Telus \\
\hline Cypsiurus parvus (Lichtenstein, 1823) & f. & $\mathrm{LC}$ & 11 & 3 & 19 & 6 & 20 & Сурра \\
\hline Apus apus (Linnaeus, 1758) & f. & $\mathrm{LC}$ & 5 & - & 7 & 9 & - & Apuaf \\
\hline Apus affinis (JE Gray, 1830) & f. & $\mathrm{LC}$ & 31 & 2 & 68 & - & 22 & Apuap \\
\hline \multicolumn{9}{|l|}{ CORACIIFORMS } \\
\hline \multicolumn{9}{|l|}{ Alcedinidae } \\
\hline Halcyon senegalensis (Linnaeus, 1766) & f. & $\mathrm{LC}$ & 3 & 6 & - & 1 & - & Halse \\
\hline \multicolumn{9}{|l|}{ Meropidae } \\
\hline \multirow{2}{*}{\multicolumn{9}{|c|}{ BUCEROTIFORMS }} \\
\hline & & & & & & & & \\
\hline \multicolumn{9}{|l|}{ Bucerotidae } \\
\hline Lophoceros fasciatus (Shaw, 1811) & $\mathrm{F}$ & $\mathrm{LC}$ & 2 & 3 & - & - & 4 & Tocfa \\
\hline \multicolumn{9}{|l|}{ PASSERIFORMS } \\
\hline \multicolumn{9}{|l|}{ Hirundinidae } \\
\hline Hirundo aethiopica Blanford , 1869 & f. & $\mathrm{LC}$ & 3 & - & - & 2 & - & Hirae \\
\hline Hirundo abyssinica Guerin-Meneville, 1843 & f. & $\mathrm{LC}$ & 5 & - & 2 & - & - & Hirab \\
\hline Motacillidae & & & & & & & & \\
\hline Macronyx croceus (Vieillot, 1816) & f. & $\mathrm{LC}$ & - & - & 6 & 3 & - & Maccr \\
\hline Anthus leucophrys Vieillot, 1818 & f. & $\mathrm{LC}$ & - & - & - & 2 & - & Antle \\
\hline Pycnonotidae & & & & & & & & \\
\hline Pycnonotus barbatus (Desfontaines, 1789) & f. & $\mathrm{LC}$ & 14 & 6 & 6 & 8 & 13 & Pycba \\
\hline Eurillas virens (Cassin, 1858) & $\mathrm{F}$ & $\mathrm{LC}$ & - & - & - & - & 1 & Andvi \\
\hline Turdidae & & & & & & & & \\
\hline Turdus pelios Bonaparte, 1850 & f. & $\mathrm{LC}$ & - & - & - & - & 1 & Turpe \\
\hline Cisticolidae & & & & & & & & \\
\hline Cisticola erythrops ( Hartlaub , 1857) & f. & $\mathrm{LC}$ & - & - & 1 & 3 & - & Ciser \\
\hline Cisticola galactotes ( Temminck, 1821) & f. & $\mathrm{LC}$ & - & - & 21 & 15 & - & Cisga \\
\hline Prinia subflava (Gmelin, 1789) & f. & $\mathrm{LC}$ & - & - & 2 & 2 & - & Caught \\
\hline Camaroptera brachyura (Vieillot, 1821) & f. & $\mathrm{LC}$ & - & - & - & - & 2 & Cambr \\
\hline Cettiidae & & & & & & & & \\
\hline Hylia prasina (Cassin, 1855) & $\mathrm{F}$ & $\mathrm{LC}$ & - & - & - & - & 1 & Hylpr \\
\hline Nectariniidae & & & & & & & & \\
\hline Cyanomitra olivacea (Smith, 1840) & $\mathrm{F}$ & $\mathrm{LC}$ & - & - & - & - & 4 & Cyaol \\
\hline Cinnyris chloropygius Jardine, 1842 & $\mathrm{~F}$ & $\mathrm{LC}$ & - & - & - & - & 4 & Cincl \\
\hline Cinnyris cupreus (Shaw, 1812) & f. & $\mathrm{LC}$ & 6 & 1 & 2 & - & & Cincu \\
\hline Cinnyris coccinigastrus (Latham, 1802) & f. & $\mathrm{LC}$ & 2 & 2 & - & - & 1 & Cinco \\
\hline Laniidae & & & & & & & & \\
\hline Lanius collaris Linnaeus, 1766 & f. & $\mathrm{LC}$ & - & - & 5 & - & - & Lanco \\
\hline Corvidae & & & & & & & & \\
\hline Corvus albus Statius Muller, 1776 & f. & $\mathrm{LC}$ & 51 & 163 & 5 & 50 & 5 & Coral \\
\hline Sturnidae & & & & & & & & \\
\hline Lamprotornis splendidus (Vieillot, 1822) & $\mathrm{F}$ & $\mathrm{LC}$ & 3 & 7 & - & 3 & 13 & Lamsp \\
\hline Passeridae & & & & & & & & \\
\hline Passer griseus (Vieillot, 1817) & f./V & $\mathrm{LC}$ & 40 & 3 & - & - & - & Pasgr \\
\hline Ploceidae & & & & & & & & \\
\hline Ploceus cucullatus (Muller, 1776) & f. & $\mathrm{LC}$ & 12 & - & 7 & 125 & - & Plocu \\
\hline Quelea erythrops ( Hartlaub , 1848) & f. & $\mathrm{LC}$ & - & - & - & 2 & - & Queer \\
\hline
\end{tabular}




\begin{tabular}{|c|c|c|c|c|c|c|c|c|}
\hline Orders / Families / Species & $\mathbf{P H}$ & IUCN & Hab & Pal & Bas & Bro & CNF & Code \\
\hline \multicolumn{9}{|l|}{ Estrildidae } \\
\hline Estrilda melpoda (Vieillot, 1817) & f. & $\mathrm{LC}$ & - & - & 5 & 16 & - & Estme \\
\hline Lonchura cucullata ( Swainson , 1837) & f. & $\mathrm{LC}$ & 5 & - & 34 & 111 & - & Specu \\
\hline Lonchura bicolor (Fraser, 1843) & $\mathrm{F} / \mathrm{f}$ & $\mathrm{LC}$ & - & - & - & 5 & - & Spebi \\
\hline \multicolumn{9}{|l|}{ Viduidae } \\
\hline Vidua macroura (Pallas, 1764) & f. & $\mathrm{LC}$ & - & - & - & 2 & - & Vidma \\
\hline
\end{tabular}

Biogéo: Biogeographic origin; PH: Preferred habitat; IUCN: IUCN Status; R: Resident; M: Intra-African migrant: P: Palaearctic migrant; E: Wetlands; F: Forest; f: Open areas; V: Anthropophilic species; A04: Sudano-Guinean biome; A05: Guinean-Congolese biome; LC: Least concern; VU: Vulnerable; Hab: Dwellings; Pal: Palm trees; Bas: Lowland; Bro: Brushwood; Code: Codes for the realization of CFA.

\subsection{Characterization of the bird population according to the abundance index}

The avifauna comprises five dominant species ( 819 individuals; $\mathrm{Fr}=59,61 \%) ; 12$ regular species $(388$ individuals; Fr $=$ 28.24\%); 23 rare species (152 individuals; $\mathrm{Fr}=11.06 \%)$ and finally 11 accidental species $(15$ individuals; $\mathrm{Fr}=1.09 \%)$ (Figure 3). In terms of preferred habitats, the population includes 34 species $(\mathrm{Fr}=81 \%)$ of open environments, ten species $(\mathrm{Fr}=4.80 \%)$ typical of forests, three species $(\mathrm{Fr}=1.31 \%)$ of wetlands, two species Passer griseus and Tyto alba, of open and anthropophilic environments $(\mathrm{Fr}=3,20 \%)$, one species Spermestes bicolor $(\mathrm{Fr}=0.36 \%)$ is found in both forests and open areas, and one species Bubulcus ibis is found in both wetlands and open areas $(\mathrm{Fr}=9.32 \%)$ (Figure 4). Based on IUCN status, 49 of the 51 species observed are of Least Concern (LC). However, two species Psitttacus erithacus and Psttacus timneh are vulnerable (V).

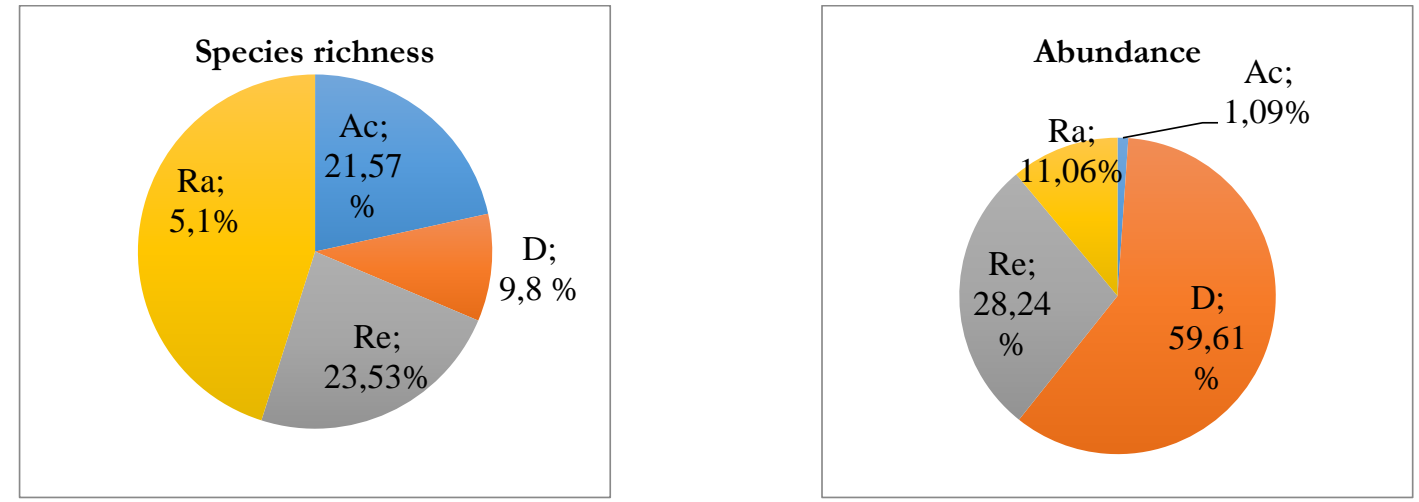

D: Dominant; Re: Regular; Ra: rare; Ac: Accidental.

Figure 3: Comparison of abundance indices according to species richness and relative abundance
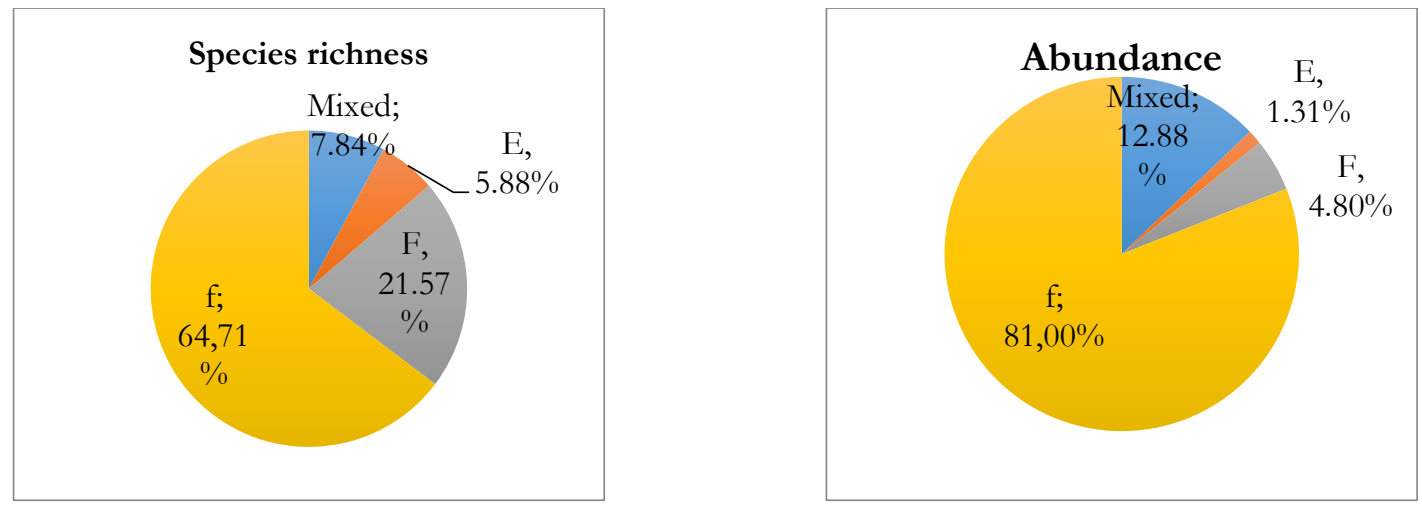

E: Wetlands; F: Forest; f: Open areas.

Figure 4: COMPOSITION of the bird population according to preferred habitats

\subsection{Avifauna of the different habitats}

The Habitations are home to 26 species of birds, with an API of 297 individuals in 18 families of nine orders, a Shannon index of 2.65 and an equitability of 0.8. Bubulcus ibis and Corvus albus, with 51 individuals each, are the most abundant. In the Lowlands, 25 species and 278 birds in eight orders and 16 families were observed, with a Shannon index of 2.55 and an equitability of 0.79 . The most abundant species is Apus affinis, with 68 individuals. At the level of the Palms, 19 species and 258 birds in eight orders and 13 families were counted, with a Shannon index of 1.65 and an equitability of 0.56. Corvus albus is the most important species, with 163 individuals. In the Brushwood, 25 species and 416 birds were 
observed in seven orders and 16 families, with a Shannon index of 2.19 and an equitability of 0.68 . The most abundant species of this habitat is Ploceus cucullatus, with 125 individuals counted. In the CNF, 23 species and 125 birds in eight orders and 13 families were surveyed, with a Shannon index of 2.67 and an equitability of 0.85. Apus affinis is the most abundant with 22 individuals (Table I).

Of the 51 species surveyed on the university campus, seven species (600 individuals; Fr $=43.67 \%)$ are common to the five habitats. These are Corvus albus, Bubulcus ibis, Cypsiurus parvus, Milvus migrans, Pycnonotus barbatus, Streptopelia semitorquata and Accipiter badius. Three species (12 individuals; Fr $=0.87 \%$ ) were observed only at Habitations. These are Chrysococcyx caprius, Tyto alba and Telacanthura ussheri. Five species (28 individuals; $\mathrm{Fr}=2.04 \%)$ are only observed in Lowland. These are Butorides striata, Amaurornis flavirostra, Gallinula chloropus, Merops pusillus and Lanius collaris. Four species (11 individuals; Fr $=0.80 \%$ ) were only observed in the Broussailles. These are Anthus leucophrys, Vidua macroura, Quelea erythrops and Lonchura bicolor. Seven species (14 individuals; Fr $=1.02 \%$ ) are only seen at the CNF. These are Andropadus virens, Turdus pelios, Hylia prasina, Cinnyris chloropygius, Cyanomitra olivacea, Accipiter tachiro and Camaroptera brachyura. No species are specific to Palms. The greatest number of species (26 species) was observed in the Dwellings. The lowest specific richness (19 species) was observed in Palm trees. The Broussailles sheltered the most birds, with 416 individuals and the $\mathrm{CNF}$ sheltered the least, with 125 birds. The most diverse habitat is that of $\mathrm{CNF}(\mathrm{H}$ '= 2.67 and $\mathrm{J}=0.85)$ and the least diverse is that of Palms $\left(\mathrm{H}^{\prime}=1.65\right.$ and $\left.\mathrm{J}=0.56\right)$. However, these various locations are not statistically different in terms of specific richness $(\mathrm{ddl}=8 ; \mathrm{F}=1.7 ; \mathrm{P}>0.05)$ and abundance $(\mathrm{ddl}=27 ; \mathrm{F}=9 ; \mathrm{P}>0.05)$ of birds.

\subsection{Distribution of birds by habitat}

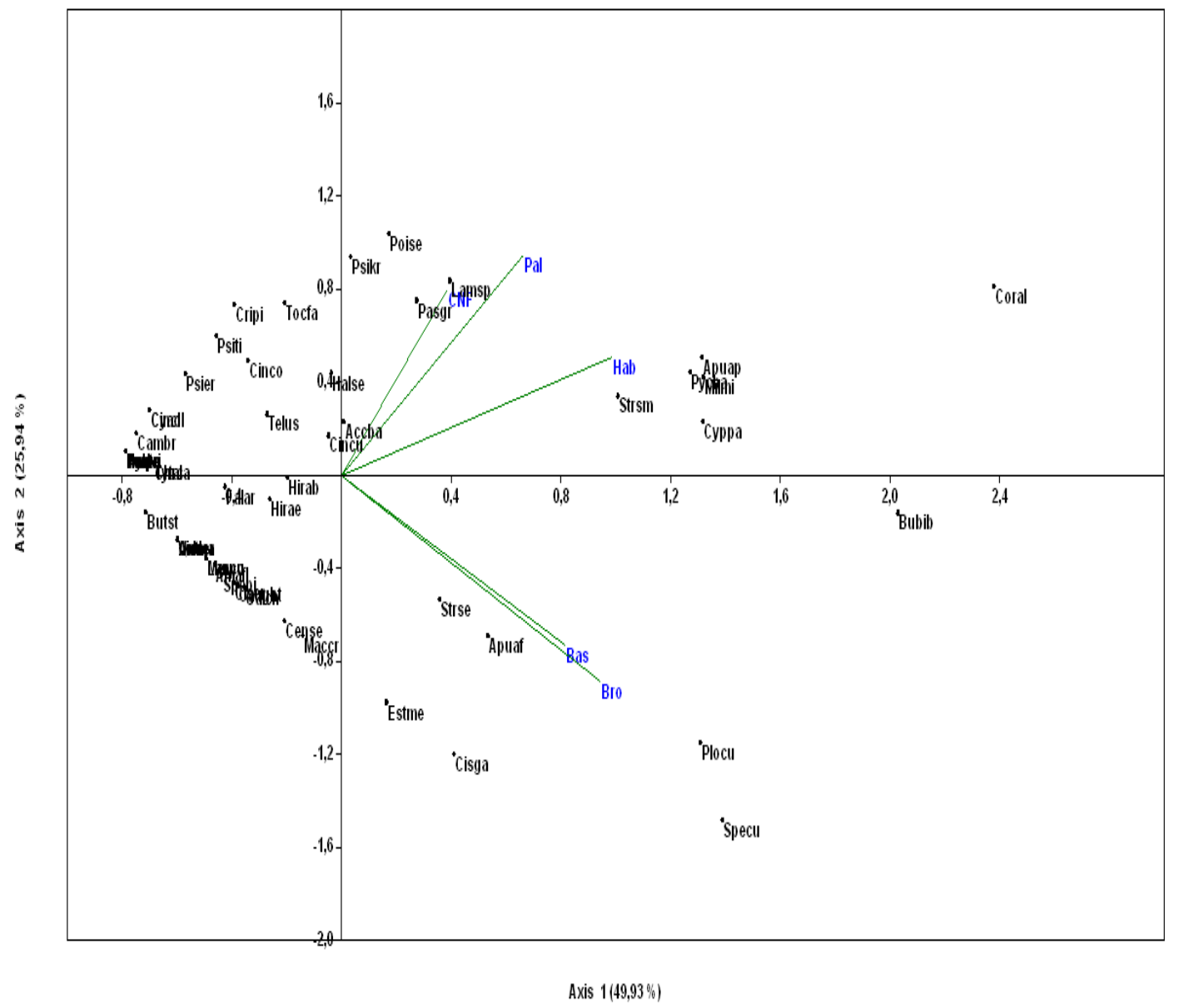

Figure 5: DISTRIBUTION of bird species according to different habitats

The study of the distribution of the bird community from a principal component analysis (Figure 5), makes it possible to distinguish two large groups of habitats with which different species of birds are associated. Indeed, the first habitat group 
positively correlated respectively by the first axis (49.93\%) and the second axis (25.94\%), represented by CNF, Pal and $\mathrm{Hab}$, is associated with the species Psittacula krameri, Accipiter badius, Poicephalus senegalus, Passer griseus, Lamprotornis splendidus, Streptopelia semitorquata, Apus apus, Cypsiurus parvus and Corvus albus. The second set, made up of the Low and Bro mediums, is positively correlated to axis 1 (49.93\%) and negatively to the second axis (25.94\%), contains the Streptopelia senegalensis, Apus affinis, Estrilda melpoda, Cisticola galactotes, Ploceus cucullatus, Lonchura cucullata and Bubulcus ibis. The General Linear Model confirms this observation by noting that the habitat significantly influences the distribution of bird species ( $\operatorname{dof}=4 ; \mathrm{W}=9.68 ; \mathrm{p}<0.05)$.

\subsection{Similarity between different habitats}

Of all the combinations made, the greatest number of common species (17 species) is recorded between Lowland and Scrub habitats. The smallest number of common species (eight species) is observed between CNF and Lowland habitats and between CNF and Brushwood. Based on the number of species common to the two habitats, the similarity index is highest for the CNF and Palm tree habitat pair $(\mathrm{Si}=76.19 \%)$ and low for the Lowland and CNF habitat pair and the Scrub and CNF habitats where it is $33.33 \%$. In addition to the similarity index, analyses with hierarchical ascending classification, on the basis of the matrices "Presence/absence of species by habitat" on the one hand and "number of individuals/species/habitat" on the other hand give dendrograms which show different associations according to the matrices considered. The dendrogram from the "number of individuals/species/habitat" matrix indicates that all habitats can be grouped into two well hierarchical groups A and B. The first group is made up of the CNF and Palm tree habitats, to which are added the Dwellings. The second group is made up of the Bas-fond and Broussailles habitats (Figure 6). The second dendrogram produced with the matrix 'Presence / absence of species by habitat' reveals three hierarchical groups A; B and C. The first group (A) is formed by the CNF, Bas-fond and Habitations habitats. The other two groups (B) and (C) are formed one by the Palm tree habitat and the other by the Brushwood habitat (Figure 7).

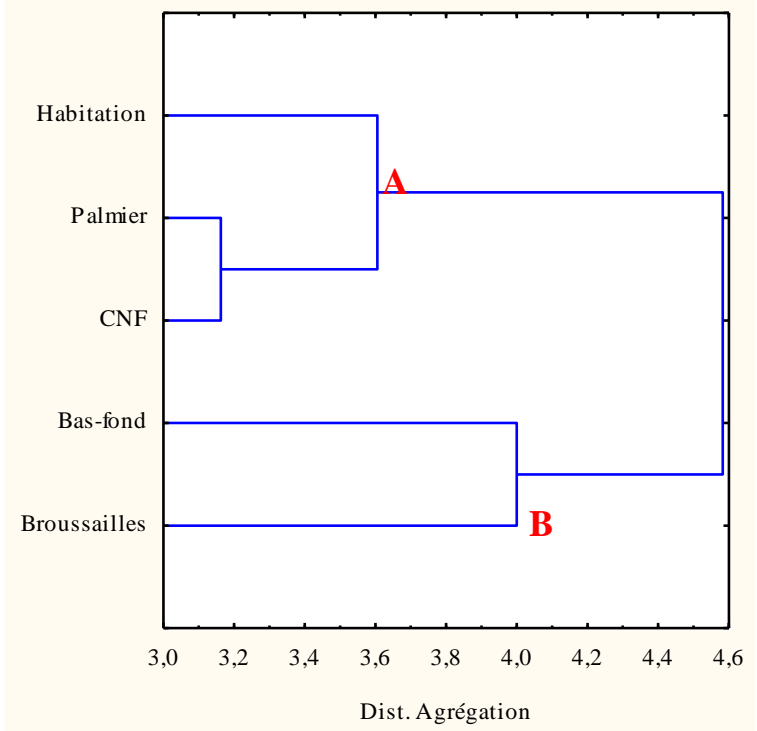

Figure 6: DENDROGRAM showing the grouping of habitats based on the abundance of species in common

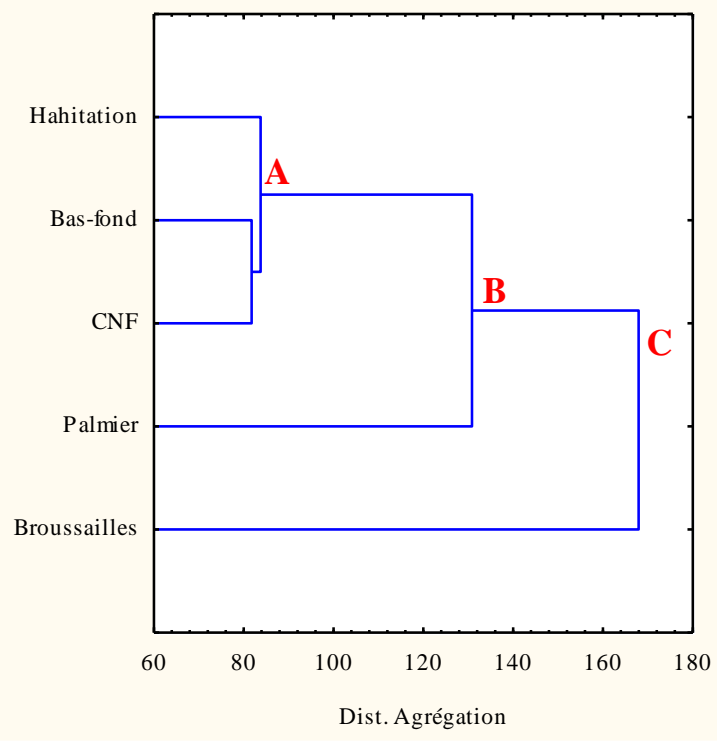

Figure 7: DENDROGRAM showing the grouping of habitats on the basis of their common specific richness

\subsection{Discussion}

This study made it possible to inventory, on the Félix Houphouet Boigny university campus, 51 species and 1374 birds. This is a very important diversity, given the short time frame (two months) of sampling and the highly urbanized physiognomy of the environment. Prior to the University's rehabilitation, a first three-month study conducted on campus in 2007 recorded the presence of 42 bird species with a cumulative population of 8,797 birds [25]. As a result of the rehabilitation, the specific richness of the environment increased while the abundance of birds decreased considerably. The rehabilitation of the campus has brought about considerable changes in its landscape. These are the remarkable expansion of the areas covered by lawns, the disappearance of fallow land and fields, the sharp reduction in trees, and the filling in of temporary ponds. This has resulted in a good individualization of the habitats which are now well isolated from each other, with a predominance of buildings and cover plants. These modifications would be at the origin of the reduction in the number of individuals, since the most gregarious species which are families of Estrildidae and Ploceidae would have been 
attracted by the cereal fields present formerly on the campus which no longer exist, as well as by an important cover of grass plants very reduced today. Rehabilitation has not profoundly affected the specific richness. Indeed, some species have been replaced by others. 12 species identified by Yaokokré-Béibro \& al. (2016) as Treron calvus, Turtur afer, Poicephalus robustus, Alcedo cristata, Hirundo rustica, Chlorocichla simplex, Cossipha niveicapilla, Ploceus aurantius, Ploceus velatus, Ploceus ocularis, Ploceus nigerrimus and Nigrita bicolor could not be observed in this study. Similarly, 18 species observed in this study were not observed in the previous study. These are Butorides striata, Accipiter tachiro, Amaurornis flavirostris, Falco ardosiaceus, Gallinula chloropus, Psittacus timneh, Tyto alba, Telacanthura ussheri, Macronyx croceus, Anthus leucophrys, Andropadus virens, Camaroptera brachyura, Cisticola galactotes, Cisticola erytrops, Cyanomitra olivacea, Hylia prasina, Turdis pelios and Quelea erytrops. This would be linked, on the one hand, to the destruction of certain suitable habitats and micro habitats such as groves, growing environments and temporary pools and, on the other hand, to the choice of habitats. In fact, in addition to the three habitats chosen during the first study (Dwellings, Brushwood and CNF), two other habitats (Lowland and Palm tree) which significantly contributed to enhancing the avifauna diversity of the campus were surveyed. The most abundant species on campus was Corvus albus. Indeed, Corvidae are birds with very diverse habitat preferences, but which have adapted to the exploitation of anthropogenic food sources [11]. The number of species observed remains comparable to those obtained by [23], in the commune of Cocody (Angré-Djibi) and by [26] at the bay of Cocody, i.e. 73 and 68 species respectively. The slightly higher number of species in these environments could be explained by longer inventories, notably 12 and 09 months, respectively. These studies show that the very high level of urbanization and the small size of the areas surveyed are the cause of low diversity.

For larger areas such as entire cities and for longer monitoring periods, campus diversity is much lower. Thus, in the cities of Yamoussoukro, Grand-Bassam and Cotonou, respectively 188 species in 24 months [15], 165 species in 12 months [24] and 115 species in 72 months [17] were identified. Considering the avifauna of each of the habitats defined in this study, some differences in quality and quantity appear. However, these do not seem to be significant. The species would use the different habitats offered by the environment for their different activities. However, contrary to [17] who reported that in Cotonou, heavily built-up areas are poor in birds, on campus, the most diverse habitat is the one with the most buildings. Indeed, several bird species prefer more densely built and sparsely vegetated areas that offer an abundance of food and are areas inaccessible to predators [3]. In addition, this could be explained by the small areas of the CNF (considered forest) and Palm tree (densely wooded garden) habitats and the lack of corridors that would allow exchanges with other urban forest sites, such as the Banco National Park. However, on the campus, each of the habitats appears to be a specific environment for a small group of bird species. Thus, 19 of the 51 species inventoried were only found in one or other of the five habitats. This shows that the conservation of birds in the city requires a combination of several habitats. According to [17], this must be achieved by safeguarding and developing wetlands and increasing the number of wooded areas. Similarly, [12] has noted the fundamental role of biodiversity reservoirs in low-density districts with trees in the city of Lyon in France.

\section{CONCLUSION AND RECOMMENDATION}

The changes that urban ecosystems regularly undergo can profoundly affect their biodiversity. The present study therefore provides a better understanding of the different variations that have occurred in the bird community of the Félix HouphouëtBoigny University Campus following its rehabilitation from 2011 to 2012. Overall, with a slightly higher species richness compared to the first pre-rehabilitation inventories, it is above all the structure of the bird community that has been profoundly modified. The choice of 05 habitats with different physiognomies made it possible to understand that tree vegetation is of vital importance for maintaining bird diversity. However, the results showed that the different environments are complementary. For a better policy of sustainable management of birdlife in the city, in addition to the influence of habitats, it is essential to understand the relationships that the various species present have with the different elements of the urban landscape.

\section{ACKNOWLEDGMENTS}

The authors are extremely grateful to Miss N'GORAN Prisca and Mr COULIBALY Siaka for their active participation in the collection of field data. Thanks are also due to the members of the ornithology research group of the UFR Biosciences of the Université Félix Houphouët-Boigny for the various proofreadings of this manuscript. Find in this article the consecration of your efforts.

\section{BIBLIOGRAPHIC REFERENCES}

[1] Barbault R., Ecologie des peuplements : structure, dynamique et évolution. Masson, Paris, 1992

[2] Bibby C., Martin J. et Marsden S., Bird survey in expedition field techniques. London. Royal Geographical Society, 1998

[3] Birard J., Les Oiseaux dans la ville, indicateurs de Biodiversités. Oiseaux et jardins : je t'aime, moi non-plus, no. 627, pp.20-22, 2014. 
[4] Blondel J., Ferry C., Frochot B., La méthode des indices ponctuels d'abondance (IPA) pour des relevés d'avifaune par "station d'écoute'. Alauda, no.38, pp.55-71, 1970.

[5] Borrow N., Demey R., Birds of western Africa. Christopher Helm, London, 2001.

[6] Borrow N., Demey R., (2012). Guide des oiseaux de l'Afrique de l'Ouest. Delachaux et Nestlé, Christopher Helm, $511 \mathrm{p}$.

[7] Brou Y., Analyse dynamique de la pluviométrie en milieu forestier Ivoirien. Thèse de troisième cycle. Université de Cocody-Abidjan, Côte d'Ivoire, 1997.

[8] Chappuis C., Oiseaux d'Afrique. 15 CDs. Paris, France. Société d'étude Ornithologique, 2000.

[9] Detroit J., «Oiseaux anthropophiles »-SOS Faune volet Oiseaux : bilan 2012. EPOB, 2013.

[10] Elander I., Lundgren Alm E., Malbert B, Sandstrôm U.G., Biodiversity in urban governance and planning: Examples from Swedish cities. Planning Theory and Practice, vol. 6, no. 3, pp.283-301, 2005.

[11] FAO., Wild Birds and Avian Influenza: an introduction to applied field research and disease sampling techniques. Edited by D. Whitworth, S.H. Newman, T. Mundkur and P. Harris. Rome. FAO Animal Production and Health Manual, 5, 2007.

[12] Frey C., Avifaune et milieu urbain : bilan et perspectives de trois années d'inventaires en quartiers denses et moins denses à Lyon - Villeurbanne. L'Effraie, no. 36, pp.19-29, 2014.

[13] Jongman R.H.G., Ter Braak C.J.F., Van Tongeren O.F.R., Data analysis in community and landscape ecology. Pudoc Wageningen, 1987.

[14] Klaus G., Ville et nature: Y a-t-il vraiment incompatibilité ? In : Biodiversité en milieu urbain. Biodiversité : Dialogue entre recherche et pratique. Hotspot, no. $8:$ pp.24, 2003.

[15] Konan E.M., Yaokokoré-Béibro K.H., Odoukpé K.S.G., Kouadja K.E.S., Avifaune de la ville de Yamoussoukro, centre de la Côte d'Ivoire. European Scientific Journal, vol. 10, no. 33, pp. 63-75, 2014.

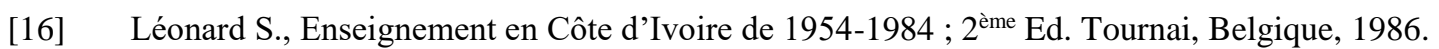

[17] Lougbégnon T.O., Codjia J.T.C., Avifaune urbaine de Cotonou et sa distribution en relation avec les facteurs de l'habitat : implication pour l'aménagement écologique de la ville. Afrique Sciences, vol. 7, no. 1, pp. 116-136, 2011.

[18] Pickett S.T.A., Cadenasso M.L., «Advancing urban ecological studies: Frameworks, concepts, and results from The Baltimore Ecosystem Study». Austral Ecology, no. 31, pp 14-125, 2006.

[19] Pimentel D., Stachow U., Takacs D.A., Brubaker H.W., Dumas A.R., Meaney J.J., O’Neil J.A.S., Onsi DE., Corzilius D.B., "Conserving biological diversity in agriculture / forestry systems". Bioscience, no. 42, pp. 354$362,1992$.

[20] Ramade F., Eléments d'écologie - Ecologie fondamentale, Ediscience-Dunod, Paris, 2003.

[21] Thiollay J.M., Structure comparée du peuplement avien dans trois sites de forêt primaire en Guyane. La terre et la vie, no. 41, pp. 59-105, 1986.

[22] Yaokokoré-Béibro K.H., Avifaune des forêts classées de l'Est de la Côte d'Ivoire : données sur l'écologie des espèces et effet de la déforestation sur les peuplements. Cas des forêts classées de la Béki et de la Bossématié (Abengourou). Thèse de doctorat unique, UFR BIOSCIENCES, Université de Cocody, Côte d'Ivoire, 2001.

[23] Yaokokoré-Béibro H.K., Koné S.Y., Odoukpé S.G.K., Gueye F.M., Avifaune d'un milieu marécageux urbain dans la commune de Cocody (Abidjan, Côte d'Ivoire. International Journal of Innovation and Scientific Research, vol. 18, no. 1, pp. 99-108, 2015a.

[24] Yaokokoré-Béibro K.H., Gueye M.F., Koné Y.S., Odoukpé K.S.G., Biodiversité urbaine des oiseaux dans la zone humide d'importance internationale de Grand-Bassam (sud-est de la Côte d'Ivoire). International Journal of Innovation and Applied Studies, vol. 11, no. 2, pp. 339-349, 2015 b.

[25] Yaokokoré-béibro H.K., Gueye. M.F., Konan E.M., Nangah D.P., Kouassi K.P., Premières données sur la diversité des oiseaux du Campus Universitaire Félix Houphouët-Boigny de Cocody à Abidjan, Côte d'Ivoire. Afrique SCIENCE, vol. 12, no. 4, pp. 67-75, 2016.

[26] Zago H.M., Avifaune de la baie de Cocody (Abidjan). Mémoire de Master de Biologie de la Conservation et Gestion de la Faune, UFR BIOSCIENCES, Université Félix Houphouët-Boigny, Côte d'Ivoire, 2014. 